\title{
Automobile - A Means of Transportation Cause of Accidents on Nigerian Roads, Its Effect on Human Life
}

\author{
Ohwojero Chamberlain Joseph \\ Delta State University Secondary School, Abraka, Nigeria
}

\section{Email address:}

cohwojero@gmail.com

\section{To cite this article:}

Ohwojero Chamberlain Joseph. Automobile - A Means of Transportation Cause of Accidents on Nigerian Roads, Its Effect on Human Life. American Journal of Mechanics and Applications. Vol. 4, No. 1, 2016, pp. 10-14. doi: 10.11648/j.ajma.20160401.12

Received: August 26, 2016; Accepted: October 5, 2016; Published: November 7, 2016

\begin{abstract}
Accident on Nigerian roads has become a serious threat and concern to every road user. Many Nigerians lost their lives through auto-crash, over $60 \%$ of Nigerians that make use of automobile as a means of mobility dies or suffer from injuries every year. Hence, this research was carried out to check and help reduce the rate of road accident on Nigerian high ways. The researcher used three companies that make use of transportation as a means of conveying goods and people as passengers. The companies are Dangote Group of Company; G. Agofure Motors and Peace Mass Transit. Data were collected through direct interview method and were analyzed using percentage, to know the frequency of road accidents. The analyses were represented on pie charts. Findings were observed and discussed after the analysis. Recommendations were made based on the findings to help reduce road accident on Nigerian roads.
\end{abstract}

Keywords: Meaning of Transportation, Meaning of Accident, Types of Automobile, Causes of Road Accidents

\section{Introduction}

The world has become very interesting for man's living because of easy movement and accessibility. Businesses are transformed for better; because of easy movement of goods and services from one location to another. All these are made possible because of transportation. Transportation has brought changes to people's lives in the rural and urban settings in Nigeria. Transportation provides economic development to an environment because it is one of the basic prerequisite for human development. Transportation can be described as an act of moving something from one place to another or a system of moving persons or goods from one position to another, that consist of three components the vehicle, guide way and the operations plan.

[12] described transportation as a means by which people and freight achieves mobility that falls in to three basic types like land, water and air. Transportation has brought changes to man's life, by making movement to be easy for man. "[7]" Assert that not only does road transport facilitate the direct provision of services to consumers, but it also provides intermediate input that entertain to the production of other sectors and raise factors of productivity. Transportation on Nigerian road has caused hazardous scene before many people who uses the road daily. In Nigeria and other developing countries especially African countries, the frequency of road accidents has become epidemic of some sort to many countries [2]. Hence, safety of human lives on Nigerian roads cannot be guaranteed. On Nigerian roads, accidents have become a disturbing phenomenon that has constituted a menace on the road. Nigerian roads have become a killing field that has no protection for its users. Many road users that travels, usually have sigh relief when they arrive their destination safely after a long journey. It has been estimated that number of registered vehicles in Nigeria between 1990 and 2006 has risen tremendous from 700,000 to $6,000,000$. This has contributed immensely to the high rate of road accident, as result of poor road condition and reckless driving. "[4]" Affirmed that in 1976 there were 53,897 road traffic accidents that claimed 7717 lives on Nigerian roads. According to World Health Organization [17] one can subdivide road crash victims into different road traffic (RTC) categories as drivers, passengers, motorcyclist, bicyclists'pedestrians and others. In 2010 record from the federal road safety commission about 5,330 people died in accident, while about 7,464 injuries are sustained on Nigerian roads. Because of caution from the Federal Road Safety Commission (FRSC) to drivers and other road users, death 
rates on Nigerian road has reduced by $12.7 \%$ in 2011 [14].

Road accidents are mostly caused by traffics, though reckless driving is one of the sources of accidents on Nigerian highway. Traffic is the major cause of road accident on the high way. Traffic accident can be described as accident that occurs when vehicle collide with another vehicle, pedestrian, animals, geographical or architectural obstacles [8]. Road traffic accident (RTA) is on the increase and presently is one of the leading causes of death on the road in the developing countries. In 2014, data collected from the Federal Road Safety Commission, about 5996 road accidents occurred that was very fatal which claimed people's life showing improvement of $8 \%$ decrease of road accident record of 2013. This shows that accident rate on Nigerian road is decreasing as a result of enlightenment campaign on the use of road [8].

The Nigerian situation of high rate of accidents on the road has reached alarming stage to the point of frustration and helplessness [14]. Nigeria as a nation continues to feature in the bottom part of World Health Organization (WHO) of traffic accidents, because in 2009 Nigeria was ranked $149^{\text {th }}$ position out of 179 countries that was faced with the hazard of road accident. The estimated number of people that was killed on Nigerian road by accident between 1990 and 2005 was 28,253 and the fatality rate still remains consistently high [3]. There was an observation by [6] that apart from the humanitarian aspect of road safety, the injuries and fatalities of road accident that occurs on Nigerian road have serious implication on a country in the area of social and economic terms. The categories of road users that are most often injured are the pedestrians, riders of two wheel cycles, vehicles, tricycle and car occupants. Road safety has become a major public health concern all over the world because it has been stated that from statistics more than 3000 people around the world die of road accident daily due to road traffic injury [16] Auto road crash has lead to global economic loss as estimated in road traffic injury that cost many US dollars of about 518 billion per year. These huge economic losses are economic burden for developing countries [10].

Summarily, transportation has contributed immensely to the development of Nigerian economy that makes life to be interesting to man. Though, the effect of auto crash on Nigerian roads has affected the health of many Nigerians who are the users of the road. Many Nigerians that travel on road are faced with the problem of high blood pressure, fear, psychological problems and other challenges that has affected the economy of the nation.

\subsection{Types of Automobiles Used on Nigerian Roads}

Automobiles used on Nigerian roads vary from one type of construction to another. They are produced by different manufacturers, almost every vehicle that ply Nigerian roads are fairly used vehicles popularly known as Tokunbo. In every five vehicles that ply on Nigerian road three out of the five are fairly used, which represent about $60 \%$ of the total vehicles used on Nigerian roads to be already used vehicles, which is one of the causes of road accident on Nigerian roads. Most vehicles that ply the Nigerian road are classified under the following headings that are represented in the diagram below in Fig. 1 .
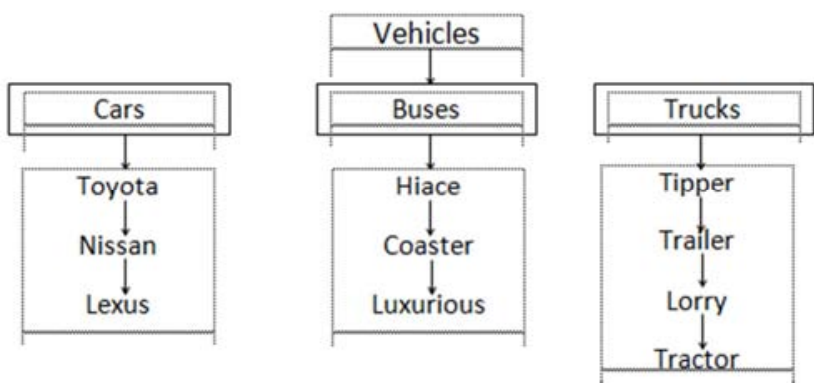

Fig. 1. Showing types of vehicles used on Nigeria.

All the above mentioned automobiles ply Nigerian roads daily, but among all these are the big trucks like trailers and buses which are the major killers of human beings on Nigerian roads. They occupy more than half diameter of the Nigerian road because of their height. They are assumed to be the giant of the road, there by becoming a treat to smaller vehicles, tricycle, motorcycle bicycles and pedestrians who also use the road.

The high population of motorist in cities like Lagos, Abuja and Ibadan etc, has caused traffic jam that has caused accident on the road in the cities. [11] Observed that over four million cars and 100,000 commercial vehicles are on the road nationwide, given an average of eleven vehicles per kilometer daily. But in Lagos where population is dense an average of 227 vehicles is found per kilometers daily that ply Lagos road comprise of trailers, buses, cars and motor cyclist.

\subsection{Causes of Road Accident on Nigerian Roads}

Accident on Nigerian road can be caused by numerous factors that are centered on human, environmental, vehicle, nature, drivers, pedestrians and passengers. [1] outlined some basic causes of road accident that promote death rate and injuries on Nigerian roads. Among the causes are:

1. Vehicle operator factor

2. Vehicle factor

3. Road pavement condition factor

4. Environmental factor

5. Speed and indiscriminate use of sirens

6. Drinking while driving and use of drugs

7. Distraction while driving

8. Inexperience in driving

9. Poor brake system

10. Vehicle light

11. Poor vehicle maintenance etc.

\subsection{Statement of the Problem}

Road accident globally has become the leading cause of death rate and injuries. It is the tenth leading cause of all deaths presently in this $21^{\text {st }}$ century. Road accident now makes up a surprisingly significant portion of the world wide 
burden of ill-health. An estimated population of 1.2 million of persons dies of auto crash every year globally. Nigeria as a nation, without any doubt harbors' the highest number of vehicles in the west coast of Africa [16] About 50million persons suffer injuries from auto crash that make up for $30 \%$ and $70 \%$ of orthopedic beds in the developing countries hospitals like Nigeria. "[15]" States that 6450 Nigerians lost their lives on road accidents in 2013 which includes 4552 men, 1398 women, 299 boys and 201girls. A close observation from the above stated data shows that men are almost four times more involved in road accident death in Nigeria.

Auto crash on Nigerian road has become a death trap for all travelers that ply the Nigerian road. Every road users mind is filled with threat, the pedestrian that walk by the side of the road is filled with fear. Accident in the recent time has become the greatest source of human and material loss [5]. Alsopedestrians in the recent times with the use of motor cycle popularly known as Okada on Nigerian road, which is one of the quickest means of transportation on Nigerian road has aggravated people exposure to danger the uncoordinated and dangerous operation of motor cyclist riders, they appear most frequently among those injured and killed in road accident. So the use of automobile on Nigerian road has become a threat to Nigerian citizens.

\section{Methodology}

\subsection{Research Design}

The survey research design was used to gather data and information in the study.

\subsection{Area of the Study}

The researcher used three popular companies that make use of vehicle as a means of transportation from the north, east and southern part of the country, the three companies are Dangote group of Company (DGC) that make use of trailers for the conveyance of goods from the northern part of Nigeria to every other part of the country. G Agofuremotors (GAM) from the southern part of the country that makes use of buses for the conveyance of passengers. Peace Mass Transit (PMT) from the eastern part of the country that make use of buses for the conveyance of passengers. The purpose of chosen these three major transport companies is that they travel farto every part of the country.

\subsection{Procedure for Data Collection}

The researcher used direct contact interview method to reach some of the drivers and staffs of the three companies in their different zonal offices were data and information was collected. The record of the Federal Road Safety Commission of Nigeria (FRSC) was also looked into where the different companies have their headquarters. The direct interview method was used by the researcher to help gather useful data.

\subsection{Collection of Data and Analysis}

The following data were collected according to the information gathered from the interview, records of the different zonal headquarters of the three transport used for the study from 2013, 2014 and 2015.

Table 1. Showing accident records on Nigerian road by DGC, GAM and PMT in 2013,2014 and 2015.

\begin{tabular}{|c|c|c|c|c|c|c|c|c|c|}
\hline \multirow{2}{*}{$\begin{array}{l}\text { Year } \\
\text { Companies }\end{array}$} & \multicolumn{3}{|c|}{2013} & \multicolumn{3}{|c|}{2014} & \multicolumn{3}{|c|}{2015} \\
\hline & DGC & GAM & PMT & DGC & GAM & PMT & DGC & GAM & PMT \\
\hline January & 2 & 0 & 0 & 0 & 1 & 0 & 1 & 0 & 0 \\
\hline February & 1 & 0 & 1 & 1 & 0 & 0 & 1 & 0 & 1 \\
\hline March & 1 & 1 & 1 & 1 & 0 & 0 & 0 & 0 & 1 \\
\hline April & 1 & 1 & 2 & 3 & 1 & 0 & 1 & 0 & 0 \\
\hline May & 2 & 1 & 1 & 0 & 2 & 0 & 1 & 1 & 2 \\
\hline June & 1 & 0 & 1 & 1 & 0 & 1 & 2 & 0 & 0 \\
\hline July & 2 & 1 & 0 & 2 & 0 & 0 & 1 & 1 & 0 \\
\hline August & 2 & 1 & 1 & 1 & 1 & 0 & 1 & 1 & 0 \\
\hline September & 0 & 1 & 1 & 0 & 0 & 2 & 0 & 1 & 0 \\
\hline October & 1 & 2 & 0 & 1 & 2 & 0 & 2 & 0 & 1 \\
\hline November & 3 & 2 & 2 & 2 & 1 & 0 & 1 & 0 & 0 \\
\hline Dec & 4 & 3 & 4 & 3 & 3 & 2 & 3 & 2 & 1 \\
\hline Total & 20 & 12 & 14 & 15 & 11 & 5 & 14 & 6 & 6 \\
\hline
\end{tabular}

\section{Analysis I}

Accident data on Nigerian roads by Dangote Group of Companies (DGC), G. Agofure Motors (GAM) and Peace Mass Transit (PMT) transport line services in 2013 are represented in percentage.

Percentage Calculation of Accident Record in each of the Companies in 2013are shown below

$\mathrm{DGC}=43.5 \%$

$\mathrm{GAM}=26.1 \%$

$\mathrm{PMT}=30.4 \%$

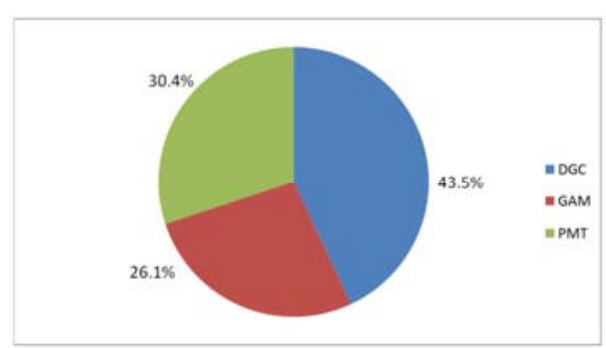

Fig. 2. Pie chart representation of accidents on Nigerian roads in 2013. 
From the percentage record on the pie chart representation shown in fig. 2, it will be observed that the percentage of accident record of Dangote Group of Company that uses trailers on Nigeria roads has $43.5 \%$ on the pie chart is higher than the percentage record representation of GAM $26.1 \%$ and PMT 30.4\%, as represented on the pie chart.

From the analyses record on the pie chart, it shows that Dangote Group of Companies that make use of trailers as a means of conveying its products through transportation has the highest accident record on Nigerian roads compared to Peace Mass Transit (PMT) and G. Agofure Motors Transport service in 2013.

Analysis II

Accident data on Nigerian roads by Dangote Group of Companies (DGC), G. Agofure Motors (GAM) and Peace Mass Transit (PMT) transport line services in 2014 are represented in percentage.

Percentages Calculation of Accident Record in each of the Companies on Nigerian Roads are shown below

$$
\begin{aligned}
& \text { DGC }=48.4 \% \\
& \text { PMT }=35.5 \% \\
& \text { AGM }=16.1 \%
\end{aligned}
$$

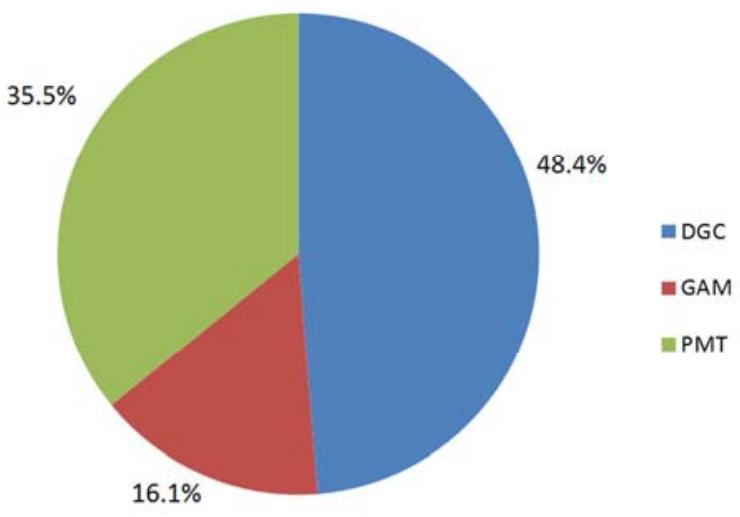

Fig. 3. Pie chart representation of accidents on Nigerian road in 2014.

From the percentage record shown on the pie chart representation of the three companies used for the study, it can be observed that the percentage record from the pie chart diagram the Dangote Group of Companies Percentage of $48.4 \%$ is higher than the accident percentage record of Peace Mass Transit (PMT) of 16.1\%, and GAM, 35.5\%. Meaning the accident record of Dangote Group of Company is higher compared to accident record of Peace Mass Transit and G. Agofure Motor (GAM) transport service in 2014.

Analysis III

Accident data on Nigerian roads by Dangote Group of Company, G. Agofure Motors and Peace Mass Transit transport service in 2015.

Percentage calculation of accident in each of the companies as shown below in 2015

DGC $=53.8 \%$
GAM $=23.1 \%$
PMT $=23.1 \%$

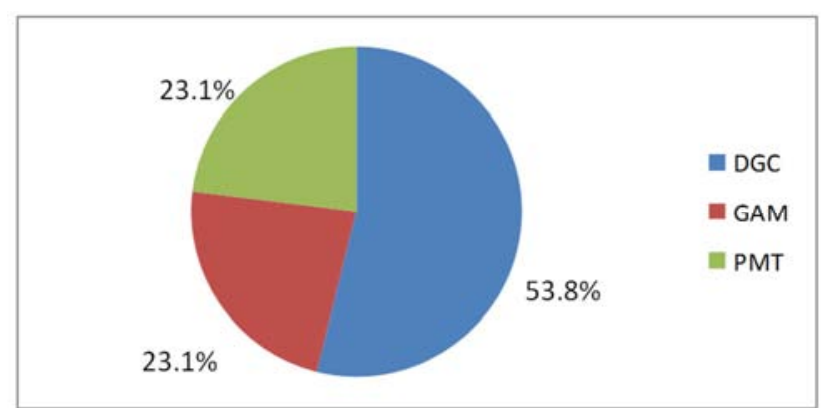

Fig. 4. Pie chart representation of accident record on Nigerian road in 2015.

From the percentage values of accident record as shown on the pie chart in fig. 4 , the percentage value $53.8 \%$ of DGC is greater than the percentage value of GAM 23.1\% and PMT value of $23.1 \%$. Therefore it can be concluded that accident rate from the DGC record is higher when compared to the two other transport lines on Nigerian roads.

\section{Discussion of Findings}

The following findings were observed and discussed after the analyses of the data and information that was collected:

1. The three companies that made use of vehicles as a means of transportation in this study have a very high record of accident in the three years.

2. Dangote Group of Company that used road transportation to convey its goods after production had the highest number of accident record on Nigeria road in the three years from the data collected.

3. There is no year that each of the companies' vehicles do not get involved in road accidents on Nigerian roads.

4. Accidents occurrence per month with Dangote Group of Companies was too frequent when compared to the other two transport lines.

5. On the pie chart table, the Dangote Group of Company occupies the highest portion of the three charts.

6. There is high loss of vehicles by the Dangote group of companies on Nigerian road checking the data collected because Dangote has the highest number of accident record compare the two other companies.

\section{Recommendation}

Based on the discussion of findings of the study, the following recommendations are made to help reduce the rate of accident on Nigerian roads:

1. The federal government of Nigeria should help to construct and repair roads in Nigeria to reduce road accident.

2. The Dangote Group of Company should be compelled by the Federal Government to use railway as a means of transporting their goods to various part of the country after production.

3. All vehicles that make use of already used tyres that has expired on Nigerian roads should be bound by the 
Federal Government of Nigeria through the Federal Road Safety Commission to reduce accident on Nigerian roads.

4. The federal government of Nigeria should place an embargo on importation of already used vehicles that is popularly known as Tokumbo into the country, to avoid road accident on Nigerian roads.

5. The federal government through the Federal Road Safety Commission should establish speed limit on Nigerian roads and any defaulter should be arraigned in a mobile court for punishment.

6. The federal government should establish emergency and intensive accident hospital units at strategic places on the federal highways to give accident victims emergency treatment when accident occurs, to save life.

7. Federal government through the Ministry of Works and Services should supervise the construction of roads to avoid the use of poor materials that will cause bad potholes on the high way, being obstacles to road users.

8. The Federal Road Safety Commission should be given the right to check year of manufacture of vehicles mileage covered by vehicles to help reduce road accident on Nigerian roads.

\section{References}

[1] Agbonkhese. O. et al. Nigerian Building and Road Research Instituted, National Laboratory Computer Kilometer O. Idiroko road. Civil and Environmental Research ISSN22250514. Vol.3. No.13. 2013. Available at www.iiste.org.

[2] Age Kameh.D. Terror on Nigerian Roads by Dele Agekameh. PremiumTimes

2014.Availableatwww.premiumtimesng.com/opinion/15327terror-nigerian-roads-dele-agekameh.html.

[3] Atubi A. O. Modeling road traffic accident in Lagos State, South West Nigeria. Journal of Society and State Vol. (2) 5774. 2009.

[4] Atubi A. O. Gbadamosi K. T. Global Positioning and socioEconomic Impact of Road Traffic Accidents in Nigeria. Matters arising. American International Journal of Contemporary Research, 2015. Vol.5, (5) 136-146.

[5] Downing A. J. Pedestrain Safety in Developing Countries The vulnerable Road user' Inter confab traffic safety. New Delhilndia, 1991.

[6] Ghee et al. Socio-Economic Aspects of Road Accidents in Developing Countries. Transport Research Laboratory library. Published by Transport Research Foundation Group of Companies. ISSN0968-4107, 1997.

[7] Ighodaro C. A. U. Road Infrastructure and Economics Growth in Nigeria. Paper presented at the First International Conference on Transport Infrastructure (ICTI) Beijing, China. April $24^{\text {th }}-26^{\text {th }}, 2008$.

[8] OECD/ITF “Nigeria” In Road Safety Annual Report 2015, OECD publishing Paris Doi:http//dx.doiorg/101787/irtad 2015-33-en, 2015.

[9] Ohakwe J. Iwueze I.S. and Chikezie D. C. Analysis of Road Traffic Accidents in Nigeria. A case study of Obinze/Nekeke/Iheagwa road in Imo State South eastern Nigeria. Asian Journal of Applied Sciences 1(4) 166-175, 2011.

[10] Pan American Health Organization Available at http://www.paho.org/English/DD/PIN/whd04-mainhtm, 2004.

[11] Raji L. (2015). The Panacea to traffic menance in Lagos. The Nation Truth in Defence of Freedom. Available at the nationonlingng.net/the-panacea-to-traffic-menace-in-Lagos, 2015.

[12] Rodrigue. P., Slack. B. and Comtois. C. Transportation Modes Modoal Competition and Modal Shift. The Geography of Transport System. Available at www.http//people.hofstra.edu, 1995.

[13] Stephen D. FRSC Releases Statistics for Road Accidents Connect Nigeria.com, 2012.

[14] Sumaila A. F. Road Crashes trends and safety management in Nigeria. Journal of Geography and Regional Planning, 2013.vol.6 (3) pp.53-62.

[15] Tega. E. Road Accident in Nigeria Analysis and Discussion in AdeyewiAdedokun. Omoju WA, 2015.

[16] Ugwu. C. (2009) Nigeria Over 7 Million Vehicle Ply Nigeria Roads Daily. Daily Champion, 2009.

[17] World Health Organization International Classification of functioning, disability and health ICF. General World Health Organization, 2001.

\section{Biography}

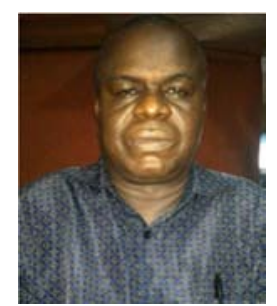

This article was written by one author as mentioned above. My names are Ohwojero Chamberlain Joseph. A Nigerian teaching Automobile Technology in the University Secondary School of the Delta State University Abraka Nigeria. I had my first degree in Industrial Technical Education measuring in Automobile Technology from the Delta State University Abraka in 1992. Second degree in Industrial Technical Education from University of Benin in 2010. I am currently studying my P.hD in Industrial Technical Education in the University of Nigeria Nsukka. I am a senior tutor, married with children. 